\title{
Understanding Challenges of Performance Measurement in a Public University:
}

\section{Evidence from Sudan}

\author{
Marwa Abdalla Alboushra ${ }^{1}$, Amirul Shah Md Shahbudin ${ }^{2} \&$ Yousif Abdelbagi Abdalla ${ }^{1}$ \\ ${ }^{1}$ School of Management Studies, University of Khartoum, Sudan \\ ${ }^{2}$ School of Management, Universiti Sains Malaysia, Malaysia \\ Correspondence: Yousif Abdelbagi Abdalla, School of Management Studies, University of Khartoum, Khartoum, \\ Sudan. E-mail: yousif3a@hotmail.com
}

Received: September 29, 2014 Accepted: October 24, 2014 Online Published: May 15, 2015

doi:10.5539/ass.v1 $1 \mathrm{n} 15 \mathrm{p} 10$

URL: http://dx.doi.org/10.5539/ass.v11n15p10

\begin{abstract}
This paper aims to understand the challenges of performance measurement implementation in higher education sector in Sudan. A qualitative case study approach is used in this study in which 23 semi-structured interviews with both internal and external administrators and directors were conducted. Documentary materials and observations are also employed to support the data generated from the interviews. The case findings reveal that several performance measurement practices in the University are adopted in a ceremonial way, which are driven by external pressure. An absence of clear strategies and plans to translate its mission and vision into workable programmes, the resistance to changes in an already established system of administration, insufficient governmental funding, and the lack of competent personnel in the field of quality and self-evaluation are the major challenges of performance measurement in the case University. Hence, the management of the University should work more closely with the concerned governmental authorities to control and overcome these challenges for successful implementation of performance measurement systems.
\end{abstract}

Keywords: performance measurement, challenges, public universities, developing countries, Sudan

\section{Introduction}

The last two decades witnessed an increasing pressure on public sector organisations to become more efficient and effective, which necessitated a great improvement in their costing and management systems, so as to provide quality and timely information (Waweru et al., 2007). Hence, the public sector was reformed and developed in order to achieve efficiency, effectiveness, and quality in public service delivery. Governments all over the world have shifted from the traditional bureaucratic management of public service and implemented the principles of the new management such as 'decentralization, flexibility, quality service, customer responsiveness and efficiency' (Sotirakou \& Zeppou, 2006). The literature highlights the significance of performance measurement (PM) as one of the ways by which organisations can ensure quality to their stakeholders (Karuhanga, 2010).

The use of performance measurement systems (PMS) in organisations in the developing countries is steadily increasing especially in Africa (De Waal, 2007; Karuhanga, 2010 ). De Waal (2007) cited a number of studies, which showed that there is an increasing interest in performance measurement and management in several countries in Africa, such as Burkina Faso, Egypt, South Africa, Kenya, Ethiopia, and Ghana. However, no study has been conducted to investigate PMS practices and the challenges of PMS in public universities in Sudan (De Waal, 2007). The slow speed of using performance measurement in higher education institutions is a critical issue that is worthy of more study (Bogt \& Sacpens, 2009, 2011; Wang, 2010). Thus, this study is motivated to investigate this issue in the higher educational sector in Sudan, given that higher education sector in Sudan is facing a large number of administrative and financial issues and challenges; especially, after what so called "Higher Education Revolution" in 1990s. These issues; amongst other things, include: an increasing number of universities and other higher educational institutions, an increasing number of students enrolled in these institutions; coupled with fewer numbers of academic staff working in these institutions. Furthermore, there is insufficient governmental funding granted to these universities. However, the slowness in change management in already established and inherited systems, as well as the lack of proper governmental funding; were the main administrative and financial challenges that clearly linked with the public university investigated in this study. 


\section{Literature Review}

\subsection{Performance Measurement Systems - Conceptualization}

The terms "performance measurement" and "performance management" complement each other, but are often confused both in practice and in the literature (Samples \& Austin, 2009). Radnor and Barnes (2007, p. 393) differentiate between the two terms as:

Performance measurement is quantifying, either quantitatively or qualitatively, the input, output or level of activity of an event or process. Performance management is action, based on performance measures and reporting, which results in improvements in behaviour, motivation and processes and promotes innovation.

The traditional conceptualization of performance measurement systems (PMSs) emphasizes the individual employee as the main focus. However, recently, several scholars have suggested that PMSs should include both internal and external information. Internal information, such as that related to production processes, and external information as pertaining to markets, customers, and competitors (Chenhall, 2003; Noeverman et al., 2005). Likewise, Ferreira and Otley (2009) mentioned that PMSs support the role of a broad range of managerial activities, including strategic processes that involve strategic formulation and implementation. In addition, through the process of learning and change, a PMS can support any emergent strategy (Ferreira \& Otley, 2009).

Performance measurement refers to the use of financial and non-financial information by managers to make decisions pertaining to organisational activities with a focus on the pre-determined goals (De Waal 2007; Karuhanga, 2010). Therefore, performance measurement refers to the set of actions put in place to determine the extent to which an organisation is achieving its pre-determined targets (Amaratunga et al., 2001). Various researchers have undertaken studies on management and measurement of performance with a focus on different issues, such as the factors affecting effective performance management in the business world, while others have focused on performance appraisals, accountability and the performance indicators for universities. However, substantive studies on performance measurement have focused on profit-making organisations (Karuhanga \& Werner, 2013).

\subsection{Challenges of PM Implementation}

Performance measurement as a mechanism of fostering improvement in service delivery still presents many challenges in its implementation, especially in most organisations working in African countries. A number of causes have been raised in the literature, such as the lack of real commitment to the PM process by organisational managers, lack of reward for good performance, absence of training, highly bureaucratic management systems, poor information system, and so on (Karuhanga \& Werner, 2013; Karuhanga, 2010, Ofori \& Atiogbe, 2011). In addition, these organisations lack sufficient financial resources, which might result in a delay or even postponement of the PM implementation (De Waal \& Counet, 2008; Ofori \& Atiogbe, 2011).

Resistance to performance measurement is considered as another obstacle to the full implementation of the performance measurement system (Bourne et al., 2000; Bourne \& Neely, 2003; De Waal \& Counet, 2008; Modell, 2003). The resistance to any new performance measurement system may come from the lack of understanding, insufficient training, and, sometimes, the fear of personal risk (Bourne \& Neely, 2003; De Waal \& Counet, 2008). In addition, De Waal and Counet (2008) highlighted other problems facing organisations in PM implementation, such as unclear strategy, lack of a performance measurement culture, organisational instability, and the low priority accorded to the PMS.

\subsection{Challenges of PM in Sudanese Higher Education: The Context}

Sudan is one of the largest countries in Africa. However, Sudan was divided into two countries with the secession of South Sudan in July 2011. Sudanese higher education is provided by universities, both public and private, as well as institutes and colleges of technical and professional education (Suliman et al., 2007). The history of modern higher education in Sudan goes back to the era of British rule. University of Khartoum - the mother of higher education in Sudan - was first established in 1902 as the Gordon Memorial College (Gasim, 2010). Higher education in the country comes under the responsibility of the Sudanese State. Later, in the 1970s, the Ministry of Higher Education and Scientific Research (MHESR) took over the responsibility for higher education (Elhadary, 2010). Historically, the funding for higher education in Sudan came from the Government, a trend which continued until the birth of the "higher education revolution" in 1990.

In the early 1990s, a series of national conferences were held to address significant changes in Sudan's political institutions, economy, peace process, and higher education. A conference on higher education recommended a reform to Sudan's higher education system. This reform was generally referred to as the "higher education 
revolution", and was designed to Arabicise, Islamise, and expands Sudanese higher education in unprecedented ways. The higher education revolution also aimed to expand the higher education in Sudan to meet the needs of the country's economic development and to keep up with the growing population (Gasim, 2010).

Since 1990, many governmental and private universities have been established, mostly outside the capital. The "reform" also introduced several legislations and institutional frameworks in the higher education sector. For example, the higher education Act of 1990 (amended in 1993 and 1995) provides the legislative basis and framework for the country's higher education. The National Council for Higher Education and Scientific Research (NCHESR) is a new body created by the Ministry of Higher Education and Scientific Research (MHESR) to take the responsibility for formulating policies and programmes of higher education within the general framework of the State national policy. However, the rapid expansion of the higher education institutions (HEIs) has resulted in a significant funding limitation. Currently, public HEIs in Sudan are facing severe financial problems, as they receive little support from the State. The level of public funding for higher education was sharply reduced when the number of universities jumped from five to thirty (Elhadary, 2010).

In conclusion, higher education in Sudan remains in a continuous state of flux dictated by the political and economic changes. There have been many problems that have hindered the achievement of the functions and objectives of higher education in Sudan. For instance, there are administrative problems, such as a lack of sufficient flexibility to cope with the change and weak management oversight, as well as the absence of management functions, such as planning, direction, coordination and control (Khalil, 2010). Hence, this paper is motivated to address such issues.

\section{Research Design and Methodology}

By utilizing a qualitative approach to investigate the challenges of PMS practices in higher education sector in Sudan, case study method is considered a suitable approach to gather and generate qualitative data. This study responds to the calls for understand a phenomenon in the natural setting and from the perspective of the organisational actors (Denzin \& Lincoln, 2000; Hancock, 2002). To choose a case university from this sector, formal request letters were sent to some universities in Sudan. A brief summary of the research was enclosed with the request letter. From all of the request letters sent, one public university replied positively to the request of becoming a case study for this research. Hence, the selection of the University was largely dependent on the availability of access to this University.

Multiple methods of data collection enable the researcher to triangulate the data and thus provide a better understanding of the PM adopted in the University (Creswell, 2007; Ospina, 2004; Yin, 2009). The interviews provide in-depth information from the various stakeholders of the University in order to understand the PM adopted. Twenty-three people from inside and outside the University were interviewed (see Tables 1 and 2). Most of the people interviewed from inside the University were chosen from various relevant hierarchical and functional departments, which included senior and junior administrators, directors, accountants and non-accountants. The external people who were interviewed included some directors and officials from the Ministry of Higher Education and Scientific Research who were concerned with the issues of funding and the performance evaluation of the universities.

The interviews mainly focused on how PM practices are used and implemented in the case University, and the challenges of such implementation in the University. The interviews were conducted at the interviewees' workplaces during the period from August to September 2012. Before conducting any interview, the interviewee was informed of the aim of the research. The interviewees were also assured of the confidentiality of the research and the information gathered from them. As such, The University is therefore referred to by pseudonym and the interviewees by their positions. All interviews were tape recorded and transcribed for data analysis.

In addition to the interviews, documentary materials and observations were employed in this study. The observations provide a basic understanding concerning how the PM adopted is implemented, while the documentary materials (such as performance reports, budgeting statements, financial statements and other relevant documents) were reviewed confirmation tool supports the information gathered from the interviews and observations. 
Table 1. List of interviews inside the University

\begin{tabular}{|c|c|c|}
\hline & Position & Interview Dates and Times \\
\hline 1 & Vice-Chancellor & 1 September 2012, 12 p.m. \\
\hline 2 & Deputy Vice-Chancellor & 9 September 2012, 8 a.m. \\
\hline \multirow[t]{2}{*}{3} & Principal & 9 September 2012, 11:50 a.m. \\
\hline & & 10 September 2012, 7:35 a.m. \\
\hline 4 & Personnel Secretary & 12 August 2012, 10:30 a.m. \\
\hline 5 & Deputy Financial Controller & 27 August 2012, 10:50 a.m. \\
\hline 6 & Academic Affairs Secretary & 2 September 2012, 9:30 a.m. \\
\hline 7 & Dean of Students & 4 September 2012, 10:40 a.m. \\
\hline 8 & Dean of Postgraduate Studies & 13 August 2012, 11:15 a.m. \\
\hline 9 & Deputy Dean of Faculty of Science & 14 August 2012, 10:40 a.m. \\
\hline 10 & Dean of Faculty of Arts & 26 August 2012, 12:40 p.m. \\
\hline 11 & Deputy Dean of Faculty of Economics & 2 September 2012, 11 a.m. \\
\hline 12 & Deputy Dean of Faculty of Engineering & 15 August 2012, 10 a.m. \\
\hline 13 & Dean of an Institute at the University & 2 September 2012, 3 p.m. \\
\hline 14 & Dean of an Institute at the University & 5 September 2012, 2:24 p.m. \\
\hline 15 & Internal Auditor & 12 August 2012, 3 p.m. \\
\hline 16 & Director of Planning & 28 August 2012, 10:5 a.m. \\
\hline 17 & Director of Self Evaluation and Quality & 28 August 2012, 11 a.m. \\
\hline 18 & Project Manager/Faculty of Engineering & 12 September 2012, 3 p.m. \\
\hline 19 & Registrar of Faculty of Medicine & 3 September 2012, 10:20 a.m. \\
\hline
\end{tabular}

Table 2. List of interviews outside the University

\begin{tabular}{lll}
\hline & Position & Interview Dates and Times \\
\hline $\mathbf{1}$ & Former-Vice-Chancellor & 27 September 2012, 2 p.m. \\
$\mathbf{2}$ & Former-Deputy Vice-Chancellor & 15 August 2012, 2.30 p.m. \\
$\mathbf{3}$ & $\begin{array}{l}\text { General Secretary of Ministry of Higher Education and } \\
\text { Scientific Research }\end{array}$ & \\
$\mathbf{4}$ & $\begin{array}{l}\text { Director of Planning/Ministry of Higher Education and } \\
\text { Scientific Research }\end{array}$ & 6 September 2012, 9:45 a.m. \\
\end{tabular}

\section{The Case Study}

Pioneer [1] is one of the first public universities established in Sudan. The vision of the University is to participate through its role in the field of higher education and scientific research. Pioneer is entrusted with providing a variety of high quality programmes at both the undergraduate and postgraduate levels. 
In order to compare the clarity of the University's objectives, several interviewees have different understandings regarding the key factors required to lead to the success of the University. These key success factors are a codification of the Vision and Mission Statements in more concrete terms and in a more compressed timeframe (Sales \& Carenys, 2013). Some interviewees mentioned factors, such as qualified academic staff, outstanding students, the ability to cope with globalisation, an active role in the community, and so on; as key elements that are necessary for the University to achieve its mission and vision.

Pioneer does indeed provide details of several targets and objectives in its Mission and Vision Statements, as well as some defined key success factors that are necessary for achieving those objectives. However, as mentioned by the Deputy Dean of the Faculty of Engineering, those Statements were considered to be theoretically in place and were not fully activated in practice. The University lacked clear plans and workable programmes to achieve its objectives:

Actually, I think the vision and mission of the University are very clear, but only on paper. We have our targets and objectives, but we don't have clear action plans to meet those objectives. (The Deputy Dean of the Faculty of Engineering)

The Deputy Dean of the Faculty of Engineering further argued that there is an absence of responsibility regarding the bodies in charge of achieving the targets and objectives that were set in those statements:

...it is not clear as to who is responsible to achieve the vision and mission: is it the Vice-Chancellor, or the Faculty Dean, or who?

The University's organisational structure is in a state of flux. Pioneer has witnessed several changes in the last three decades, which ultimately resulted from the policies of higher education revolution. These changes include: an increasing number of institutions and centres, as well as expansion in students numbers, increasing number of academic staff, shrinking of the governmental support in the budget of the University. As a result of such changes, it becomes impossible to follow a central style of administration for the University. The centralisation system, which has prevailed for decades in the University, is considered as a heavy burden on the senior-level of management of the University. Several Deans and heads of departments have complained of the delay in performing their duties. Therefore, the University decided to revise its administrative organisation and restructure its units from centralisation to decentralisation; to allow for more freedom and decentralised decision-making, as highlighted by the Vice-Chancellor of the University:

The decentralisation was applied in [the late 2000s], in order to give more freedom for the Deans and heads of departments. Now, there is a head for each campus. This framework was also adopted to improve the quality of the work, and to speed up the decision-making process.

Although the decentralisation has been adopted in Pioneer, there are many things that are still centralised. For example, the appointment of professors and teachers, the decisions of scientific research and scholarship, the attraction of qualified personnel for various institutes and faculties, and so forth are centralised. As noted by the Dean of an Institute at the University, such centralised decisions have affected the flow of the management processes in the University:

The University claims the adoption of the decentralisation policy; however, I think that claim is just a slogan and was not fully activated in practice. For instance, the faculties do not have the full right to dispose of their funds unless they have received the approval of the Principal of the University.

Hence, many things remain centralised, with a low-level of autonomy afforded to the middle managers. Therefore, the decision-making process in the University is still what is referred to as "from the top-down".

The University lacks the clear plans and workable programmes to achieve those objectives. However, in 2011, the first written strategic plan was established at the University, as mentioned by the Director of Self Evaluation and Quality:

The University does not have a vision for strategic plans. The University has the vision and mission, but there is no clear strategy, and the University regulations have not been updated since its early establishment. However, since 2011, the University have its own four year strategic plan.

Currently, Pioneer has an established system of decision-making which originated at the Departmental-level, Faculty Boards, the University Senate, and the University Council. In the University there is a body which is termed the "Planning Council" (PC). The PC provides assistance to the various faculties, centres, and institutions in the preparation of their plans to ensure the plans align with the University's strategy. 
Currently, the process of implementing strategic planning in the University faces many problems. There is a lack of awareness amongst some members of the University about the importance of the planning in itself, not only on the level of junior management but also within the level of senior management, as confirmed and supported by the observations conducted by the first author during the informal conversations with the various directors of the University. Moreover, there is a lack of cooperation between the various units of the University and the planning administration, as stated by the Director of Planning Administration:

Our main problem is the lack of interaction between the planning administration and other units of the University. To convince people about the importance of planning is a big problem, even at the level of senior management. I'm a member of the Planning Board in the State, and I think the idea of conducting planning is considered as a relatively new issue in Sudan.

Several directors of the University have acknowledged that financial indicators related to expenditures and revenues (such as the amount of government funds, amount of income from research, income from different fees and services, periodic reports of expenditures on facilities/ library/ and sports facilities, expenditures rate, and comparison between the disbursed and estimated figures) are important because they enable the University to carry out its programmes and have a strong impact on its academic performance, as further explained by the Principal of the University:

Usually we have a deficit when comparing between the disbursed and estimated figures, which might have a negative impact on the activities of the faculties, especially the science faculties. Parts of the activities of those faculties are the scientific tours. Some of these tours have been cancelled because of the cost or sometimes, cutting down the cost through reducing the period of these basic academic programmes in the University.

The Vice-Chancellor of the University also highlighted the meagre of funds as the main reason that preventing the University to achieve its objectives:

Funding is a major obstacle to achieve some of the objectives of the University, such as improving the learning environment, staff development and training, students' extracurricular activities, and so forth.

Accordingly, those situations make it difficult for various units of the University to achieve the goals set in their strategies, including the PM plans and programmes.

\section{Case Findings}

\subsection{PM Practices in Pioneer}

The establishment of a clear link between an organisation's strategic objectives and performance measurement practices is considered as one of the main features of integrative Performance Measurement Systems (PMS) (Ferreira \& Otley, 2009; Santos et al., 2012; Yap \& Ferreira, 2010). Since the main objectives of Pioneer have been identified as teaching and learning, research and community service, then ideally, PM practices should be based on those objectives.

Before the mid of 2000s, it seems that there have been no systematic mechanisms to measure performance in the University. However, and due to governmental pressures, the University established a unit for self-evaluation at the University level, as well as sub-units of self-evaluation at the faculties' level. Through such units, the University has adopted formal indicators for measuring the performance that was developed by the Ministry of Higher Education and Scientific Research. The University has introduced several Key Performance Indicators (KPIs) in order to monitor its performance, facilitate the assessment and evaluation of its operations, and to provide information for external quality assurance audits undertaken by different bodies (for example, Ministry of Higher Education, Ministry of Finance, academic accreditation bodies, and so on). These KPIs covered the main activities that constitute the mission of the University (teaching, research, and community service).

The main focus of Pioneer is on the students' academic performance. Through the teaching and learning window, the students' performance is monitored in terms of different input and output indicators, such as the number of intake of students (Bachelor, Master, or Diploma), number of academic staff, students/academic staff ratio, student progress and achievement (contact hours, seminars, examinations, success and failure rates, number of students accepted/graduated ratio, and so on), and the quality of teaching, as stated by the Project Manager at the Faculty of Engineering:

In the field of performance measurement, the University is always focusing on the academic performance using various measurements. Examples of such measurements include examinations, seminars, and the opinions of different beneficiaries. 
To assess the teaching process and to help the University to improve and upgrade the academic performance, in the mid of 2000s, the University introduced a uniform course evaluation system (in the form of questionnaires), which allowed students to evaluate every course and every teacher. These questionnaires included a number of aspects, such as good teaching, clear and concise goals for courses, appropriate measurement, appropriate assignments and homework, basic skills, and overall satisfaction. These evaluation indicators have only recently been adopted and designed. However, they have not actually been used to measure the teaching performance as the teachers objected to conducting such an evaluation method, explained the Director of Self Evaluation and Quality:

Sometimes, there is a resistance to change from some people, which could be a misunderstanding. For example, when we designed a questionnaire for taking the opinion of the students on the teachers' performance, the teachers protested on conducting of such evaluation.

On the second objective of the University (scientific research), several interviewees mentioned that performance is monitored through the number of researches and publications in the national and international journals, research income and grants, number of doctorates conferred, and so on. Regarding the community service objective, the University adopted some formal indicators developed by government bodies (MHESR as an example). Such indicators include projects such as training and consultations, the level and the role of the University in the service of society, and the resolution of issues. However, several interviewees argued that there is no certain measure to assess the success or failure in the areas of community service, noted the Director of Self Evaluation and Quality:

The University focuses on the scientific research and education performance, but our future vision is the service of the society, and how to measure for such objective. The University offers a lot of services to the community.

Generally, in any university there are a number of factors influencing a university's performance measurement. These include instruction facilities, academic staff, staff experience and skills, and commitment and motivation (Wang, 2010). Currently, the PM in the Pioneer faces a number of problems, such as a lack of qualified and experienced staff, lack of training at the University level, the difficulty to change the inherited administration system, poor financial resources, and the migration of teachers, as stated by the Academic Affairs Secretary:

...Problems related to performance measurement in the University include a lack of qualified and trained staff; that we cannot take advantage of them to improve and measure the performance, lack of financial resources, and the migration of teachers. Thus, how we can get a suitable academic environment in such situations?

In summary, the case University measures its performance through various measurement systems. However, the focus is on academic performance (the learning) through formalised measures for teaching and learning. However, these measures which have been formally adopted have not been fully implemented in practice.

\subsection{Performance Evaluation in Pioneer}

Performance measurement system is mainly assessed because of external and internal demands. For instance, in the teaching and learning aspects, the University is required to submit annul performance reports to the National Council of Higher Education and Scientific Research, which is responsible for the evaluation of the performance of the Sudanese higher institutions. Evaluation of the University performance is also carried out by higher educational institutions at the international as well as at the regional level. Members of these institutions visit the University on a regular basis to examine the effectiveness of teaching and learning, and to evaluate and measure the quality of the degrees which have been conferred.

Internally, there is the Scientific Affairs Secretariat, which is considered as a supervisory body to the various faculties and institutes in the University regarding academic performance. At the end of each academic year, the entire Faculties' Deans have meetings with their academic staff to discuss the performance. Following on from that, all the faculties and institutes are required to submit annual academic performance reports to the Scientific Affairs Secretariat. These reports are then compared to the previous year's reports to determine the level and trend of academic performance. Consequently, the Scientific Affairs Secretariat will send the annual academic performance reports to the various boards in the University to accordingly undertake appropriate decision-making.

Performance evaluation in the University is discussed at three levels: at the individual's level, the faculties' and departments' level, and at the University's level. At the individual's performance level, the University has academic staff and non-academic staff. For the non-academic staff, there is a standard format for this assessment 
by their departments at the end of the year and this specifies a ranking from 1 to 10 . The ranking of 1 was attributed to employees who have weak performance, and the ranking of 9 or 10 was allocated to those who demonstrated excellent performance. These assessment forms are subsequently reported to the administration of human resources. The main aim of such assessment is to provide an annual evaluation about the employees' performance and to identify any difficulties facing them in undertaking their duties. Such periodic assessment reports are the only standard for assessment, which governs the promotions, salary increments, and the continuity of the employees in their jobs.

As per the academic staff, the University has no certain criteria to evaluate their performance, as stated by the Secretary of the Scientific Affairs:

Unfortunately there is no way to evaluate the teachers' performance; however, there is a plan to do an assessment by students, scientific research published, and the teaching hours.

Notwithstanding this, at the departmental level, there are instances of academic staff having regular discussion with their subordinates about their performance. For example, the deans and heads of different departments in the University have faculty and departmental regular review meetings with their staff to discuss the plans, activities and performance for their units. These meetings cover both financial and academic aspects. In general, the promotion of the academic staff is based primarily on the number of years spent in teaching, as well as the number of publications made in the national and international journals.

One of the key mechanisms used by University to evaluate its overall performance is the annual performance reports of the various faculties and departments. Those reports covered different aspects, such as teaching, students' results and examinations, staff training, and so forth. In addition, these annual reports are then forwarded to the senior-level management of the University to closely monitor the performance of the faculties, as further explained by the Deputy Dean of the Faculty of Sciences:

The performance is evaluated through the annual performance reports at all levels, which includes teaching, results and examinations, staff training, programmes and so on. The reports are submitted to the University's top management for assessment. If there is any shortcoming, the respective faculty will be questioned.

In summary, the performance evaluation processes at the University, departmental, and individual levels are largely dependent on the periodical and annual financial and academic reports. These reports provide information on the performance of these parties. The reports are submitted to various internal and external bodies. For instance, internally, all the financial reports are to be submitted to the University Council through the Financial Administration; to evaluate financial performance and to take actions accordingly. In addition, annual financial reports are to be submitted to the Ministry of Higher Education and Scientific Research and Ministry of Finance as external parties. Likewise, both academic and financial annual performance reports are discussed at the University Boards and presented at the University Council before being submitted to the National Council of Higher Education and Scientific Research.

Moreover, at the University level, Pioneer has established an administration for Self Evaluation and Quality, as well as sub units for this administration in all faculties; to improve the performance evaluation and quality of performance in the University. This administration has commenced using different variations of assessment tools, such as conducting unannounced visits to faculties and schools to evaluate their actual performance, sending questionnaires to the students and teachers to get their responses about the teaching performance, and so on.

Nevertheless, the Administration of Self Evaluation and Quality in the University has faced the problem of not having competent staff and the financial resources necessary to perform its duties and responsibilities. In addition, there is a lack of awareness among the members of the University regarding the importance of the issues of quality and self-assessment, as highlighted by the following quotes from the interviews:

We have an administration to assess the performance of the University. In addition, we have quality and self-assessment units in all the faculties and institutes of the University. But they were not well activated. The reasons can be the lack of the awareness about the importance of the subject, as well as there is no competent staff in those units. (The Dean of Students Ship)

...we lack the place where we can deliver what is required from us, and we also lack the financial resources needed to perform our duties. For example, if we want to analyse the performance evaluation questionnaires, we must go to a third party and this will slow down the completion of the work. (The Director of Self Evaluation and Quality) 
Concisely, the main shortcomings of the PM practices in the case University are as follows. Firstly, there are identified weaknesses due to the lack of annual academic appraisals for academic staff. Secondly, there is slowness in change management in an already established system for transition from a traditional to a modern University. Thirdly, there is a lack of proper funding. Finally, there is also a continuous migration of teachers from the University to Arab Gulf countries.

\section{Discussion}

Pioneer has a vision and mission, which are clearly stipulated the objectives to be achieved by the University, however, the University has no specific and clear strategies to break down those objectives into workable plans. Therefore, the initiatives undertaken, such as the adoption of the decentralisation system, the establishment of strategic planning and quality management and self-evaluation procedures are simply undertaken by the University in a ceremonial way to meet isomorphism pressures. Strategy is the way through which the organisation selects to follow over the long-term for achieving its organisational objectives. In that vein, strategy has been considered as a key element in the PMS (Chenhall, 2003; Ferreira \& Otley, 2009).

Despite the University recently formalising its strategic planning, there are many problems facing the University. In order for the University to achieve the targets set in relation to those plans, measures ought to be taken to address the problems, such as an absence of responsibility regarding the bodies in charge of achieving the targets and objectives. As there does not seem to be clear agreement concerning what constitutes the key success factors in the University. There is also a lack of cooperation between the various units of the University and the planning administration. These problems represent challenges for the successful implementation of the University's target plans. Essentially, strategic planning must be linked to annual action planning and individual performance (Kaplan, 2001). In addition, PM requires that at the end each year, all staff in the organisation ought to be able to see the way in which they are contributing to the organisation's objectives (Kuzilwa, 2012). Having a clear vision and a detailed strategy alone is not enough. The implementation process of the strategy is more challenging to an organisation's management than simply defining the vision and objectives (Karuhanga, 2010; Karuhanga \& Werner, 2013).

The lack of awareness and resistance to change also represents an obstacle to the full implementation of PM in the University. For example, one of the most important reasons for the non-application of the criteria for evaluating the performance is the resistance encountered by some members of the University. The resistance was not only at the level of academic staff but also at the level of senior management. For instance, there is a slowness of change in an already established system for transition from a traditional to a modern university. Hence, the resistance to the new systems, such as the decentralisation system and evaluation programmes, might lead to the ceremonial implementation of those systems rather than full implementation (Bourne et al., 2000; Modell, 2003).

Furthermore, in the case University there is a poor link between the PM practices and the rewards system, as shown from the "Employees Appraisal and Assessment Documents" issued in 2011. This is consistent with the problems of PM identified by the interviewees. Several prior studies found that if there is no link between the PMS and the evaluation and rewards system, organisational members will not be evaluated and rewarded for their good performance (De Waal, 2007; De Waal \& Counet, 2008; Karuhanga, 2010). This situation might lead organisational members to consider issues regarding the PMS as not being very important.

The dearth of the Government funding is considered as the main challenge for the University by almost all the interviewees. The Government funding is insufficient and always represents a barrier to achieve the strategies and objectives of the University. In addition, the inadequate Government funding has also had an adverse effect on the level of academic performance. The low financial conditions for teachers, together with an absence of rewards of good performance at the University, have led to a huge migration of the majority of teachers to Arab Gulf universities. As such, the lack of number of teachers, given the increasing number of students, has led to a focus on teaching at the expense of scientific research, as highlighted by the Former-Deputy Vice-Chancellor:

One of the main factors that led to the weakening of scientific research at the University is the shortage of teachers in comparison with the large numbers of students, which has led to focusing on the teaching performance at the expense of scientific research. Moreover, the low financial conditions for teachers together with the absence of rewards have led to a negative impact on the performance of teachers, and on their outcome of scientific research.

Such problems were also shown in the "Documents of Decentralisation" in the case University that were reviewed by this study. The inadequate funding constrains the implementation of management plans in the universities because it leads to financial crisis and the breakdown of the universities' activities (Karuhanga, 2010; 
Shun et al., 2006). For instance, as a result of inadequate funds, Pioneer has a poor information communication infrastructure with no connectivity in the large parts of the University. This problem has a negative impact on the University's activities because the communication is slow, as well as some documents get lost or delayed as a result of using the manual communication systems with very poor information networks. The problem of a limited access to information represents a challenge for setting and implementing the PM in the University. An efficient and effective information flow system plays an essential role in the communication and data collection processes (Bourne et al., 2000; Ferreira \& Otley, 2009; Yap \& Ferreira, 2010).

Besides the internal factors, there are also external factors which have contributed to the ceremonial PM practices in the case University. For example, all universities are required to submit annual performance reports to the National Council of Higher Education and Scientific Research. However, it appears that these reports were not discussed seriously, and are simply part of the routine activities of the universities to comply with the policies and procedures issued by the NCHESR, as noted by the General Secretary of the Ministry of Higher Education and Scientific Research:

All universities have submitted annual reports - that covered academic, administrative, and financial aspects - to the National Council for Higher Education and Scientific research. However, these reports were not discussed seriously, unless there is a big problem. They are just part of the routine agenda of the Council.

He furthered emphasised the need to review those performance evaluation reports in order to strengthen the control and follow-up over the performance of the universities.

\section{Conclusion}

The main objective of this paper is to understand the challenges of PM in Sudanese public universities. Pioneer was chosen as a case study in this research. There are several challenges faced by the University in implementing effective PM practices. These challenges include: (1) an absence of clear strategies and plans to translate the mission and vision of the University into workable programmes; (2) the resistance to changes in an already established system of administration; (3) insufficient governmental funding; and (4) the lack of competent personnel in the field of quality and self-evaluation. Therefore, it appears that the process of adopting PM practices in the University has only been carried out in a ceremonial way to respond to external pressures rather than being fully implemented in the University's management practices.

This study suffers from the typical common limitation of case research, that is, the issue of generalizability. The study focuses on only one public university in Sudan. As such, the results of this research might not be conclusive in giving a general picture in all universities in Sudan. Differences in the historical background of those universities, for example, may invite different PM challenges that should be viewed and tackled differently. However, for future research, this study might be a good starting point to conduct a comparative case study between several universities with respect to the case subject. The comparison of how two or more universities are analysed in terms of PM adoption will enhance both the body of knowledge and practical outcomes.

Finally, much of the prior research on PM in higher education has been undertaken in developed countries. This paper extended the theory and practice in this area of research by investigating the challenges of PM practices of a University located in a developing country.

\section{References}

Amaratunga, D., Baldry, D. \& Marjan, S. (2001). Process improvement through performance measurement: the balanced scorecard methodology. Work Study, 50(5), 179-188. http://dx.doi.org/10.1108/EUM0000000005 677

Bogt, H. J., \& Scapans, R. W. (2011). The management of performance in universities-NPM and some of its effects. Paper presented at the EGPA conference, Bucharest (Romania).

Bogt, H. J., \& Scapens, R. W. (2009). Performance measurement in universities: a comparative study of two A \& $F$ groups in the Netherlands and the UK. Paper presented at the 7th ENROAC Conference, Dundee, Scotland.

Bourne, M., \& Neely, A. (2003). Implementing performance measurement systems: a literature review. Business Performance Management, 5(1), 1-24. http://dx.doi.org/10.1504/IJBPM.2003.002097

Bourne, M., Neely, A. D., Mills, J. F., Platts, K., \& Wilcox, M. (2000). Designing, implementing and updating performance measurement systems. International Journal of Operations \& Production Management, 20(7), 754-771. http://dx.doi.org/10.1108/01443570010330739 
Chenhall, R. H. (2003). Management control systems design within its organizational context: findings from contingency-based research and directions for the Future. Accounting, Organizations and Society, 28, 127-168. http://dx.doi.org/10.1016/S0361-3682(01)00027-7

Creswell, J. W., \& Clark, D. V. L. P. (2007). Designing and conducting mixed methods research. Thousand Oaks: CA: Sage Publications.

De Waal, A. A. (2007). Is performance management applicable in developing countries? The case of a Tanzanian college. The International Journal of Emerging Markets, 2(1). http://dx.doi.org/10.1108/174688007107 18903

De Waal, A. A., \& Counet, H. (2008). Lessons learned from performance management systems implementations. International Journal of Productivity and Performance Management, 58(4), 367-390.

Denzin, N. K., \& Lincoln, Y. S. (2000).Handbook of qualitative research (2nd ed.). London: Sage.

Elhadary, Y. A. E. (2010). The higher education "revolution" in Sudan and its impact on research in higher education institutions. National Higher Education Research Institute, (16), 9-11.

Ferreiraa, A., \& Otley, D. (2009). The design and use of performance management systems: an extended framework for analysis. Management Accounting Research, 20, 263-282. http://dx.doi.org/10.1016/j.mar. 2009.07.003

Gasim, G. (2010). Reflecting on Sudan's higher education revolution under Al-Bashir's regime. Comparative \& International Higher Education, 2, 50-53.

Hancock, B. (2002). An introduction to qualitative research. Trent Focus Group, University of Nottingham.

Kaplan, R. S. (2001). Strategic performance measurement and management in non-profit organizations. Non-profit Management \& Leadership, 11(3), 353-370. http://dx.doi.org/10.1002/nml.11308

Karuhanga, B. N. (2010). Challenges of performance management in universities in Uganda. Paper presented at the International Research Symposium in Service Management, Le Meridien Hotel, Mauritius, August 24-27.

Karuhanga, B. N., \& Werner, A. (2013). Challenges impacting performance management implementation in public universities: A case of Uganda. African Journal of Economic and Management Studies, 4(2), 223-243. http://dx.doi.org/10.1108/AJEMS-Nov-2011-0103

Khalil, S. (2010). Higher education in Sudan: The problems and solution. Retrieved from http://www.alrakoba.net/articles-action-show-id-1535.htm

Kuzilwa, J. A. (2012). Challenges workload allocation models and human resources management in universities. Paper presented at the 4th Higher Education Forum, Mumble University, Naura Springs Hotel, Arusha, September 13-14.

Modell, S. (2003). Goals versus Institutions: The development of performance measurement in the Swedish university sector. Management Accounting Research, 14, 333-359. http://dx.doi.org/10.1016/j.mar.2003. 09.002

Noeverman, J., Koene, B. A., \& Williams, R. (2005). Construct measurement of evaluative style: a review and proposal. Qualitative Research in Accounting \& Management, 2(1), 77-107. http://dx.doi.org/10.1108/ 11766090510635398

Ofori, D., \& Atiogbe, E. (2011), Strategic planning in public universities: a developing country perspective. Business and Management, 1(7), 68-85.

Ospina, S. (2004). Qualitative Research. London, Thousand Oaks CA, New Delhi Sage Publications.

Radnor, Z. J., \& Barnes, D. (2007). Historical analysis of performance measurement and management in operations management. International Journal of Productivity and Performance Management, 56(5/6), 384-396. http://dx.doi.org/10.1108/17410400710757105

Sales, X., \& Carenys, J. (2013) Case study on performance management: A comprehensive approach. British Journal of Economics, Management \& Trade, 3(2), 73-88. http://dx.doi.org/10.9734/BJEMT/2013/2829

Samples, M., \& Austin, M. (2009). Performance management in nonprofit human service organizations. Retrieved from http://www.mackcenter.org/docs/Performance\%20 Management.pdf

Santosa, M., Lucianettib, L., \& Bourne, M. (2012). Contemporary performance measurement systems: A review 
of their consequences and a framework for research. Management Accounting Research, 23, 97-119.

Shun, H., Chen, C. C. Y., \& Jiun, Y. S. (2006). The application of a balanced scorecard in the performance evaluation of higher education. The Total Quality Management Magazine, 18(2), 190-205.

Sotirakou, T., \& Zeppou, M. (2006). Utilizing performance measurement to modernize the Greek public sector. Management Decision, 4(9), 1277-1304. http://dx.doi.org/10.1108/00251740610707730

Suliman, A. A. M., Raman, M., \& Hamid, R. A. (2007). ICT for higher education in Sudan: issues and perspectives: Managing Worldwide Operations \&Communications with Information Technology, 971-975.

Wang, X. (2010). Performance measurement in universities: managerial perspective (MA. Thesis). University of Twente.

Waweru, N., Porporato, M., \& Hoque, Z. (2007). Performance measurement practices in Canadian government departments. http://dx.doi.org/10.2139/ssrn.1003813

Yap, P., \& Ferreira, A. n. (2010). The complex and multifaceted world of performance management in NGOs: A Case Study. Retrieved from http://www.eiasm.org/userfiles/file/2011/NiceProgramme5July.doc

Yin, R. K. (2009). Case study research design and methods. London: Sage Inc.

\section{Note}

Note 1. For reason of confidentiality this name is a pseudonym.

\section{Copyrights}

Copyright for this article is retained by the author(s), with first publication rights granted to the journal.

This is an open-access article distributed under the terms and conditions of the Creative Commons Attribution license (http://creativecommons.org/licenses/by/3.0/). 